\title{
Colon Cancer Reversed by Phyto-Nutritional Therapy: A Case Study
}

\author{
Steve Yap*
}

DSY Wellness and Longevity Center, Kuala Lumpur, Malaysia

\begin{abstract}
Colorectal cancer is the second most common cancer in Malaysia and up to $80 \%$ of its patients seek complementary therapies. Globally, up to $95 \%$ of cancer patient use adjunct therapies to reduce chemotherapy-induced side-effects. Morgan et al. (2004) had showed that conventional treatment for colon cancer produced minimal results. The vast majority of cancer survivors admitted to using dietary supplements and herbs after their cancer diagnosis. Current treatment seems to pay more attention to cancer as a disease rather than meeting the physiological needs of the patient. Nutritional therapy should be individually tailored since dietary deficiency is multifactorial and the tumor burden for each patient is different. Cancer is a metabolic disorder and colon cancer is strongly associated with advancing age, dietary and lifestyle habits. Up to $90 \%$ of all cancers might be prevented with proper nutrition since one-third of overall cancer deaths are linked to malnutrition. This case study shows how a late stage colon adenocarcinoma might be completely reversed by evidence-based phyto-nutritional therapy combined with some lifestyle modifications. The cancer apoptotic properties of this natural protocol warrant further investigation involving a higher number of patients with similar conditions.
\end{abstract}

Keywords: Colon cancer, metabolic disorder, complementary medicine, phyto-nutritional therapy, apoptosis.

\section{CASE PRESENTATION}

Alice W, age 44 and single, worked as an accounts executive in a printing company. With recommendation from a friend, she called at DSY Wellness Center to learn more about non-invasive therapy after she was diagnosed two weeks' earlier at a leading private hospital as suffering from stage III colon adenocarcinoma. She was against the idea of having her tumor surgically removed and then to undertake chemotherapy to address malignant cells which might metastasize during such an operation. In addition, she did not wish to face the possibility of having to maintain for life a "toilet bag" outside of her lower abdomen should subsequent surgery fail to reattach her severed colon.

Four years' earlier she rejected a private hospital's advice to undergo a colonoscopic polypectomy to remove some of her inflamed adenomatous polyps. Besides ulcerative colitis diagnosed two years' ago and a history of early diabetes, there were no major symptoms at time of consultation. Bleeding stools were infrequent but constipation was a problem. The hospital's colonoscopy and biopsy reports confirmed the malignancy.

The patient was fond of having preserved or canned food, toasted bread or cereals, fruit jam, packaged fruit juices for her breakfast. Lunch would usually consist of

\footnotetext{
*Address correspondence to this author at the DSY Wellness and Longevity Center, Kuala Lumpur, Malaysia; Tel: 60-3-42701266; Fax: 60-3-42701831; E-mail: dsy@dsywellness.com
}

Asian fast food with soft drink or sugary beverage. In between meals, she would have titbits with canned beverage or caffeinated drink. She enjoyed grilled meat, fish, or sausages, and deep-fried foods which she prepared for herself for most evenings. She admitted to having little or no daily fresh vegetables, fruits, nuts, beans, or seeds.

Despite several years' of medications, her diabetes remained poorly controlled. Her body mass index (BMI) of 30.8 would place her in the obese category. Consequently, a comprehensive ketogenic (lowcarbohydrate/sugar) dietary cum lifestyle modification program was recommended as follow:

(a) Temporarily replacing red and processed meat with non-farmed poultry, meat and fish which are high in quality protein useful for treating late stage malignancy [1]. Both red and processed meat intakes could raise colorectal cancer risk by $20 \%$ [2], although the association with red meat appears to be stronger for rectal cancer [3]. Mutagens are often found in deep-fried, grilled food, food preservatives or colourings, and pesticide residuals in food.

(b) Avoiding grilling or cooking any meat or fish over open flame to reduce formation of heterocyclic amines (mutagenic compounds that damage cell deoxyribonucleic acid or DNA), which are formed from added sugar and from several chemicals found in meat including its amino acids and creatine [4]. 
(c) Increasing intake of fiber-rich fresh organic vegetables and fruits, as well as bran cereals and legumes since these foods are known to reduce colon cancer risk [5]. Just 30 gram dietary fiber daily could reduce risk of developing colorectal cancer. Cruciferous vegetables are rich in cancer-fighting nutrients such as sulforaphane, indole-3-carbinol and glucosinolates which have been shown to promote apoptosis (programmed cell death) and to induce the expression of the tumorsuppression p53 gene via estrogen-independent action. Tomato contains lycopene which could prevent colon cancer too $[6,7]$.

(d) Eating foods rich in omega-3 fatty acids such as those from anchovy, deep-sea fish, and raw nuts since they can reduce risk of developing colon cancer [8]. Brazil nuts, for instance, contain as much as 190 micrograms $(\mathrm{mcg})$ of the antioxidant selenium per 10 grams [9]. Dietary selenium deficiency is associated with an increased risk of fatal cancer [10].

(e) Including non-GMO (genetically modified organism) soy products such as protein isolate and tempeh in her diet. Epidermal growth factor (EGF)-induced proliferation of colon cancer cells plays an important role in colon cancer progression and is mediated by loss of tumor suppressor FOXO3 activity. Genistein (a compound of soy isolate) can inhibit EGFinduced proliferation, while favoring dephosphorylation and nuclear retention of FOXO3 in colon cancer cells [11]. The benefits of consuming soy foods against colorectal cancer may extend to more advanced age for women [12].

(f) Having generous servings of anthocyanin-rich organic fruits and berries since these might inhibit growth of colon cancer cells by some $50 \%$ in just a few days [13]. Naringenin (flavonoid found in citrus fruits and tomato) is also known to have anti-carcinogenic properties by strongly inhibiting proliferation of colon cancer cells. Myricetin from berries is a potent inhibitor of matrix metalloproteinases enzyme responsible partly for colon cell metastasis [14]. A higher dietary intake of fresh organic vegetables [15] and vitamin $\mathrm{C}$ from berries and fresh fruits reduces the risk of colon cancer [16]. (g) Avoiding refined starch, sugar, or honey and consuming moderate quantity of organic nonGMO whole grains, which are associated with a lower risk of colon cancer although not of rectal cancer [17].

(h) Adding generous amount of spices to cooking. Flavonoids in turmeric and onions could reduce both the size and number of precancerous lesions in intestinal tract. The number of colon polyps might drop 60 percent, and their average size might drop by 50 percent [18]. Dietary curcumin such as from curry powders is known to suppress colon tumor volume by more than $50 \%$ compared to diet without this flavonoid [19]. Ginger contains highly active flavonoid gingerol6, which could induce apoptosis and inhibit metastasis [20]. Diosgenin from fenugreek seeds may induce apoptosis via caspase-3 [21].

(i) Having regular yellow or green tea as beverage since its polyphenols could prevent the development of tumors by blocking angiogenesis (growth of new blood vessels) [22]. In addition, tea polyphenols are able to scavenge highly reactive hydroxyl radicals and are effective against peroxide-induced mitochondrial damage or radiation induced DNA damage implicated in various types of carcinogenesis (cancer creation) [23].

(j) Eating raw or lightly cooked garlic might decrease risk of colorectal cancer by 30\% [15]. Studies suggest that adding garlic to diet could help prevent several types of cancer, particularly colon cancer [24, 25]. Even aged garlic could reduce risk of colon cancer [26].

The lifestyle modifications recommended included 30-minute physical exercise daily before evening meal such as walking, swimming, jogging, or similarly light aerobic workout since low physical activity is a risk factor for colon cancer [27].

The following herbal extracts and nutraceuticals were prescribed to be taken after meal:

Curcumin (standardized to $90 \%$ with $5 \%$ black pepper oil): 2 grams (g) three times a day (TID). A daily dose of just $3.6 \mathrm{~g}$ of curcumin (principal curcuminoid in curcuma loga) could achieve pharmacologically efficacious levels in the colorectum with negligible distribution of curcumin outside the gut [28]. There seems to be 
no dose-limiting toxicity at doses up to $10 \mathrm{~g} /$ day [29]. Curcumin can inhibit cancer at its initiation, promotion and progression stages of development [30]. It is a COX2-inhibitor with both anti-inflammatory and antioxidant properties. It is able to positively affect gene transcription and to induce apoptosis [31]. Curcumin-induced apoptosis is mediated through activation of caspase-3 whereas its inhibition of carcinogenesis may be mediated through inhibition of angiogenesis [32].

(2) Annona muricata: $5 \mathrm{~g}$ of powdered leaf and seed extracts TID. Compounds in this tropical fruit tree are selectively cytotoxic to colon adenocarcinoma cells [33]. Studies showed its annocherimolin had cytotoxic potencies much higher than those of adriamycin (chemotherapy drug) against colon (HT-29) cancer cell lines [33, 34], whereas its acetogenins could have significant cytotoxicities against colon adenocarcinoma cell lines [35].

Artemisinin: $500 \mathrm{mg}$ TID, which was the dosage used in accordance with World Health Organisation recommendations based on the patient's body weight [36]. Studies showed this extract from Artemisia annua $L$. to be highly effective against colon cancer [37, 38] with its triterpene and sesquiterpene capable of destroying colon cancer cells [39]. The herb's effectiveness seems comparable to other standard chemotherapy drugs used to combat cancer, but it has the distinct advantage of very low toxicity $[40,41]$ and with several hundred years of continuous use in traditional Chinese medicine [42]. Artemisia is recognized in United States as a food item [43] and many Orientals add this herb to brew tea or to make a soup. Most cancer cells aggressively accumulate iron for their proliferation. Artemisinin reacts with iron within these malignant cells to destroy them, but normal cells unsaturated with iron remain virtually unharmed by this flavonoid [44-46]. It is this combination of iron (ferritin) and artemisinin that is known to be effective against malignant cells [47-49].

(4) Resveratrol (standardized to $40 \%$ ): $500 \mathrm{mg}$ TID. This nutrient helps to suppress colon cancer cell proliferation and to enhance apoptosis even in the presence of the hormone IGF-1 via suppression of IGF-1R/Akt/Wnt signaling pathways and activation of p53 [50]. The combination of curcumin and resveratrol could inhibit growth of p53-positive and p53-negative colon cancer HCT-116 cells [51]. Being oilsoluble, resveratrol offers a protection against lipid peroxidation in cell membranes and DNA damage caused by reactive oxygen species (ROS) [52].

(5) Selenium yeast: $250 \mathrm{mg}$ TID (equivalent to elemental selenomethionine $300 \mathrm{mcg}$ ). This mineral may offer $50 \%$ reduction in cancer death [53] and it decreases incidence of colon cancer by some $50 \%$ [54]. Just $200 \mathrm{mcg}$ of selenium is able to lower the risk of developing colorectal cancer [55].

(6) Anchovy fish oil extract (EPA500/DHA200): $2 g$ TID. These omega-3 fatty acids reverse inflammation and cachexia by inhibiting lipid mobilizing factor (LMF) produced by tumors, which then causes direct breakdown of adipose (fat) tissues [56]. Eicosapentaenoic acid (EPA) in fish oil is a LMF inhibitor. Anchovy oil seemed to have the lowest level of toxicity amongst all fish oils tested at the Center and there was no evidence of significant blood-thinning effect observed in this patent at this dosage.

As a preventive measure, the patient was also advised to take these nutrients after meal:

(a) Folate: $1 \mathrm{mg}$ TID. Low blood levels of folate increases risk of colon and other cancers [57]. Studies suggest that folate deficiency predisposes individuals toward developing cancer of the colon $[58,59]$. It may also reduce the risk of recurrent polyps [60].

(b) Calcium carbonate: $1 \mathrm{~g}$ TID. Several studies found calcium supplementation reduced risk of colon cancer [61-65]. Its benefits may continue for some years after supplementation has stopped [66].

(c) Magnesium citrate: $1 \mathrm{~g}$ TID equivalent to $450 \mathrm{mg}$ of elemental magnesium. Low magnesium intake has been linked to increased risk for colorectal cancer [67]. This mineral is helpful in treating diabetes since it is a component of the hormone insulin.

(d) Mixed tocopherols: 200mg TID. Although studies are mixed, but overall they suggest that 
high intake of vitamin $\mathrm{E}$ is associated with reduced risk of colon cancer [68-71].

(e) Vitamin D3: 4000iu TID. Several epidemiological studies reported higher risk of colon cancer in individuals having low intake of vitamin D [7275]. However, one study found no association when carried out on patients living in sunny climates [76] where they already had adequate vitamin D synthesis through sunlight exposure.

The patient was advised to continue with her $80 \mathrm{mg}$ aspirin prescribed by her regular physician for blood thinning since this non-steroid anti-inflammatory drug (NSAID) could also work to block enzyme cyclooxygenase2 (COX-2), which promotes inflammation and cell division. Tumors make an abundance of COX-2 and low-dose NSAID has a moderate chemo-preventive effect on adenomas in the colon [77] and could reduce the risk of fatal colon cancer [78]. However, prolong aspirin use is associated with a dose-related increase in incidence of gastrointestinal complications [79] and hemorrhagic stroke [80].

\section{CAUSES AND PATHOLOGICAL ISSUES}

Colorectal (bowel) cancer - the third most common cause of cancer death around the globe - originates from epithelial cells carrying mutated APC (adenomatous polyposis coli) gene lining the colon or rectum of gastrointestinal tract [81]. It is the second most frequent cancers for both sexes in Malaysia [82]. Between 75 and $95 \%$ of colon cancer occurs in people with little or no genetic risk [27, 83] and none of this patient's siblings had ever been diagnosed with this condition.

Although research studies show a significant link between the gene TGFBR1 (transforming growth factor beta receptor type 1 gene polymorphisms) and colon cancer $[84,85]$, this genetic test was unavailable.

Besides constipation with occasional blood in her stools and unexplained fatigue, the patient experienced no major symptoms. While rectal bleeding or anemia are high-risk features [86], the classic warning signs include worsening constipation, bloody stool, weight loss, loss of appetite and even nausea or vomiting in some cases.

Most colorectal cancer occurs due to lifestyle and advancing age. Indeed, it is being known for decades that up to $90 \%$ of most cancers could be prevented with proper nutrition [87]. However, most nutritionist and dietician are not trained to offer advice on or to administer nutritional therapy to cancer patients. At least one-third of overall cancer deaths are linked to malnutrition [88] and infection both of which are preventable by properly targeted nutritional therapy.

People with inflammatory bowel disease such as ulcerative colitis or Crohn's disease are at increased risk of colon cancer [89]. Studies also found diabetes to be associated with an increased risk of colorectal cancer [90].

The patient's anaerobic gut bacterium Enterococcus faecalis was not tested for although this might play a role in the pathology of colon cancer [91] since its toxins can effect DNA mutations.

Adequate vitamin $\mathrm{D}$ in the diet can help prevent colon cancer [92]. Consequently, a person's blood level for calcidiol $[25(\mathrm{OH}) \mathrm{D}]$ is a useful marker to test. If levels are between 33 and $41 \mathrm{ng} / \mathrm{mL}$, patient may be five times less likely to develop colon cancer [93]. Not surprisingly, death from colon cancer is less likely in those who lived in sunny regions of the world [94]. The patient in question had been avoiding the sun for years for fear of developing accelerated skin aging. Individuals with circulating serum 25(OH)D levels below $30 \mathrm{ng} / \mathrm{mL}$ may double the risk of colon cancer compared to those with higher levels [ 93, 95-97] and much higher cancer incidence for those with levels lower than $20 \mathrm{ng} / \mathrm{mL}$ [98]. The 25(OH)D levels are associated with risk of colon cancer during both its early and late stages $[93,99]$ suggesting that vitamin $D$ metabolites may have effects at all stages of carcinogenesis [100, 101].

While cancer stage may be a major determinant of the patient's quality of life, the impact of nutritional deterioration combined with deficiencies in nutritional intake may be more important than the stage of the disease process [102].

Conventional cancer treatment may not extend much the average survival of patients and there seems to be no significant improvement in treatment outcomes or reduction in absolute - rather than relative- risks since 1980s [103].

\section{DIAGNOSIS}

The patient's localized bowel cancer was diagnosed through colonoscopy - which is commonly used for screening and surveillance of colorectal neoplasia [104] 
Table 1: Extracts from Patient's Blood Test Results for the First Four Month of 2012

\begin{tabular}{|c|c|c|c|c|c|}
\hline & March & April & May & June & July \\
\hline $25(\mathrm{OH}) \mathrm{D}(>30 \mathrm{ng} / \mathrm{mL})$ & 18 & 27 & 46 & 56 & 61 \\
\hline CA $19-9(<35 \mathrm{U} / \mathrm{ml})$ & 393 & 311 & 224 & 98 & 54 \\
\hline CEA $(<5 \mathrm{ng} / \mathrm{ml})$ & 20.6 & 11.2 & 7.6 & 3.1 & 2.9 \\
\hline $\mathrm{HbA1c}(<5.1 \%)$ & 9.3 & 8.7 & 8.3 & 7.8 & 7.2 \\
\hline Fasting insulin (2-25ulU/ml) & 84.5 & 66.3 & 55.8 & 48.3 & 40.8 \\
\hline Fasting glucose $(<115 \mathrm{mg} / \mathrm{dl})$ & 215 & 168 & 145 & 102 & 93 \\
\hline Triglycerides $(<200 \mathrm{mg} / \mathrm{dl})$ & 404 & 358 & 272 & 208 & 187 \\
\hline Hs-CRP (<1.0mg/L) & 16.9 & 14.4 & 10.8 & 5.4 & 3.5 \\
\hline \multicolumn{6}{|l|}{ Physical statistics: } \\
\hline Skeletal muscle (\%) & 21.4 & 22.7 & 23.6 & 25.3 & 25.8 \\
\hline Total body water (>55\%) & 42.7 & 44.2 & 46.6 & 47.4 & 49.1 \\
\hline Total body fat $(<25 \%)$ & 38.1 & 36.4 & 32.5 & 30.3 & 26.7 \\
\hline BMI (21-24) & 30.8 & 28.4 & 27.3 & 26.2 & 25.7 \\
\hline
\end{tabular}

- and a tissue biospy. Additionally, blood markers strongly suggested existence of malignancy. However, virtual colonoscopy (CT colonography) was not done since this procedure seemed less effective in detecting small lesions than traditional colonoscopy besides carrying a radiation risk. Radiation exposure causes approximately $3 \%$ of all cancers since this method creates the very reactive hydroxyl radical (ROS) widely implicated in cellular mutations. The less invasive sigmoidoscopy, pill camera, and the annual fecal immunochemical blood test might not offer the same levels of accuracy as colonoscopy. Although removing adenomatous polyps of the colon and rectum through colonoscopic polypectomy could result in a lower incidence of colorectal cancer [105], this invasive procedure was rejected by the patient some years' ago.

\section{CONCLUSION}

Although the test for Colon Cancer Specific Antigen2 was unavailable, biopsy report in July from a leading local hospital confirmed the disappearance of the patient's malignancy with a substantial regression for her colon tumor size. Table 1 test results strongly suggested that a well-targeted phyto-nutritional therapy was effective against colon cancer especially in its less advanced stage and the overall outcome achieved warrant further investigation involving higher number of patients with similar conditions.

\section{REFERENCES}

[1] Ravasco P, Monteiro Grillo I, Marques Vidal P, Camilo M. Nutritional deterioration in cancer: the role of disease and diet. Clin Oncol 2003; 15: 443-50.

http://dx.doi.org/10.1016/S0936-6555(03)00155-9

[2] Cross AJ, Leitzmann MF, Gail MH, Hollenbeck AR, Schatzkin $A$, et al. A prospective study of red and processed meat intake in relation to cancer risk. PLoS Med 2007; 4(12): 325. http://dx.doi.org/10.1371/journal.pmed.0040325

[3] Larsson S, and Wolk A. Meat consumption and risk of colorectal cancer: a meta-analysis of prospective studies. Int J Cancer 2006; 119(11): 2657-64. http://dx.doi.org/10.1002/ijc.22170

[4] Layton D, Bogen KT, Knize MG, Hatch FT, Johnson VM, et al. Cancer risk of heterocyclic amines in cooked foods: an analysis and implications for research. Carcinogenesis 1995; 16: 39-52.

http://dx.doi.org/10.1093/carcin/16.1.39

[5] Aune D Chan DS, Lau R, Vieira R, Greenwood DC, et al. Dietary fibre, whole grains, and risk of colorectal cancer: systematic review and dose-response meta-analysis of prospective studies. BMJ 2011; 343. http://dx.doi.org/10.1136/bmj.d6617

[6] Gionvannucci E. Tomatoes, tomato-based products, lycopene, and cancer: review of the epidemiological literature. J Natl Cancer Inst 1999; 91: 317-31. http://dx.doi.org/10.1093/inci/91.4.317

[7] Franceschi S, Bidoli E, La Vecchia C, Talamini R, D'Avonzo $\mathrm{B}$, et al. Tomatoes and risk of digestive-tract cancers. Int $\mathrm{J}$ Cancer 1994; 59: 181-4. http://dx.doi.org/10.1002/ijc.2910590207

[8] Hall M, Chavarro JE, Le IM, Willett WC, Ma J. A 22-year prospective study of fish, n-3 fatty acid intake, and colorectal cancer risk in men. Cancer Epidemiol Biomarkers Prev 2008; 17: 1136-43.

\section{http://dx.doi.org/10.1158/1055-9965.EPI-07-2803}

[9] U.S. Department of Agriculture, Agricultural Research Service. 2013. USDA National Nutrient Database for Standard Reference, Release 26. Nutrient Lists. 
http://ndb.nal.usda.gov/ndb/nutrients/report/nutrientsfrm?max $=25 \&$ offset $=0$ \& totCount $=0$ \& nutrient $1=31$ \& nutrient $2=$ \&nutrient $3=\&$ subset $=0 \& \mathrm{fg}=\&$ sort $=$ c \& measureby $=\mathrm{g}$. Accessed: September 26, 2013.

[10] Salonen J, Salonen R, Lappetelainen R, Maenpaa $\mathrm{PH}$, Alfthan $\mathrm{G}$, et al. Risk of cancer in relation to serum concentrations of selenium and vitamins $A$ and $E$ : matched case-control analysis of prospective data. Br Med J 1985; 290: 417-20.

[11] Qi W, Weber CT, Wasland K, Savkovic SD. Genistein inhibits proliferation of colon cancer cells by attenuating a negative effect of epidermal growth factor on tumor suppressor FOXO3 activity. BMC Cancer 2011; 11:219. http://dx.doi.org/10.1186/1471-2407-11-219

[12] Gong Y, Shu XO, Li H, Chow WH, Cai H, et al. Prospective cohort study of soy food intake and colorectal cancer risk in women. Am J Clin Nutr 2009; 89(2): 577-83. http://dx.doi.org/10.3945/ajcn.2008.26742

[13] Zhao C, Giusti MM, Malik M, Moyer MP, Maqunson BA. Effects of commercial anthocyanin-rich extracts on colonic cancer and nontumorigenic colonic cell growth. J Agric Food Chem 2004; 52(20); 6122-8. http://dx.doi.org/10.1021/jf049517a

[14] Ko C, Shen SC, Lee TJ, Chen YC. Myricetin inhibits matrix metalloproteinase 2 protein expression and enzyme activity in colorectal carcinoma cells. Mol Cancer Ther 2005; 4(2): 281-90.

[15] Steinmetz KA, Kuchi LH, Bostick RM, Folsom AR, Potter JD. Vegetables, fruit, and colon cancer in the lowa Women's Health Study. Am J Epidemiol 1994; 139: 1-15.

[16] Cohen M, Bhagavan HN. Ascorbic acid and gastrointestinal cancer. J Am Coll Nutr 1995; 14: 565-78.

[17] Larsson S, Bergkvist L, Wolk A. Magnesium intake in relation to risk of colorectal cancer in women. JAMA 2005; 293(1): 86-9.

http://dx.doi.org/10.1001/jama.293.1.86

[18] Cruz-Correa M, Shoskes DA, Sanchez P, Zhao R, Hylind LM, et al. Combination treatment with curcumin and quercetin of adenomas in familial adenomatous polyposis. Clin Gastroenterol Hepatol 2006; 4(8): 1035-8. http://dx.doi.org/10.1016/j.cgh.2006.03.020

[19] Rao CV, Rivenson A, Simi B, Reddy BS. Chemoprevention of colon carcinogenesis by dietary curcumin, a naturally occurring plant phenolic compound. Cancer Res 1995; 55(2): 259-66.

[20] Pan MH, Ho CT. Chemopreventive effects of natural dietary compounds on cancer development. Chem Soc Rev 2008; 37: 2558-74.

http://dx.doi.org/10.1039/b801558a

[21] Raju J, Rao CV. Diosgenin, a steroid saponin constituent of yams and fenugreek: emerging evidence for applications in medicine. In: Iraj Rasooli, ed. Bioactive Compounds in Phytomedicine. Shanghai: InTech 2012; pp. 125-42.

[22] Cao Y, Cao R. Angiogenesis inhibited by drinking tea. Nature 1999; 398: 381. http://dx.doi.org/10.1038/18793

[23] Anderson RE, Fisher LJ, Hara Y, Harris T, Mak WB, et al. Green tea catechins partially protect DNA from $\mathrm{OH}$ radicalinduced strand breaks and base damage through fast chemical repair of DNA radicals. Carcinogenesis $2001 ; 22(8)$ : 1189-93. http://dx.doi.org/10.1093/carcin/22.8.1189

[24] Fleischauer AT, Poole C, Arab L. Garlic consumption and cancer prevention: meta-analyses of colorectal and stomach cancers. Am J Clin Nutr 2000; 72: 1047-52.

[25] Dorant E, van den Prandt PA, Goldbohm RA, Hermus RJ, Sturmans F. Garlic and its significance for the prevention of cancer in humans: a critical view. Br J Cancer 1993; 67: 4249.
[26] Tanaka S, Haruma K, Kunihiro M, Nagata S, Kitadai Y, et al. Effects of aged garlic extract (AGE) on colorectal adenomas: a double-blinded study. Hiroshima J Med Sci 2004; 53: 3945.

[27] Watson A, Collins P. Colon cancer: a civilization disorder. Digestive Diseases 2011; 29 (2): 222-8. http://dx.doi.org/10.1159/000323926

[28] Garcea G, Berry DP, Jones DH, Sing R, Dennison AR, et al. Consumption of the putative chemopreventive agent curcumin by cancer patients: assessment of curcumin levels in the colorectum and their pharmacodynamic consequences. Cancer Epid Biomarkers Prev 2005; 14(1): 120-5.

[29] Aggarwal B, Kumar A, Bharti AC. Anticancer potential of curcumin: preclinical and clinical studies. Anticancer Res 2003; 23(1A): 363-98.

[30] Nagabhushan M, Bhide S. Curcumin as an inhibitor of cancer. J Am Coll Nutr 1992; 11(2): 192-8.

[31] Sharma R, Gescher AJ, Steward WP. Curcumin: the story so far. Eur J Cancer 2005; 41(13): 1955-68. http://dx.doi.org/10.1016/j.ejca.2005.05.009

[32] Arbiser JL, Klauber N, Rohan R, van Leeuwen R, Huang MT, et al. Curcumin is an in vivo inhibitor of angiogenesis. Mol Med 1998; 4(6): 376-83.

[33] Zeng L, Wu FE, Oberlies BH, McLaughlin JL, Sastrodihadjo $\mathrm{S}$. Five new monotetrahydrofuran ring acetogenins from the leaves of Annon amuricata. J Nat Prod 1996; 59(11): 103542.

http://dx.doi.org/10.1021/np960447e

[34] Kim DH, Ma ES, Suk KD, Son JK, Lee JS, et al. Annomolin and annocherimolin, new cytotoxic annonaceous acetogenins from Annona cherimolia seeds. J Nat Prod 2001; 64(4): 502-6. http://dx.doi.org/10.1021/np000335u

[35] Kim GS, Zeng L, Alali F, Rogers LL, Wu FE, et al. Two new mono-tetrahydrofuran ring acetogenins, annomuricin $\mathrm{E}$ and muricapentocin, from the leaves of Annona muricata. J Nat Prod 1998; 61(4): 432-6. http://dx.doi.org/10.1021/np970534m

[36] Phillips-Howard P. Regulation of the quality and use of artemisinin and its derivatives. In: Artimisia. Wright CW ed. London: Taylor and Francis 2002.

[37] Efferth T, Dunstan H, Sauerbrey A, Miyachi H, Chitambar $\mathrm{CR}$. The malarial artesunate is also active against cancer. Int J Oncol 2001; 18: 767-73.

[38] Singh N, Lai, H. Synergistic cytotoxicity of artemisinin and sodium butyrate on human cancer cells. Anticancer Res 2005; 25(6): 4325-31.

[39] Kwon C. Phytochemical constituents of Artemisia stolonifera. Arch Pharm Res 2001; 24(4): 312-5.

http://dx.doi.org/10.1007/BF02975098

[40] Klayman D. Qinghaosu (Artemisinin): Antimalarial drug from China. Science 1985; 238: 1049.

[41] Efferth T. Molecular pharmacology and pharmacogenomics of artemisinin and its derivatives in cancer cells. Cur Drug Targets 2006; 7: 407-21.

\section{http://dx.doi.org/10.2174/138945006776359412}

[42] Willcox M. Artemesiaannua as a traditional herbal antimalarial. In: Willox M, Bodeker G, Rasoanaivo P. Eds.Traditional Medicinal Plants and Malaria. New York: CRC Press 2004; p. 46.

[43] Schaller J. The use of the herb artemisinin for babesia, malaria and cancer. Florida: Hope Academic Press 2006.

[44] Lai H, Narendra S. Selective cancer cell cytotoxicity from exposure to dihydroartemisinin and holotransferrin. J Cancer Lett $1995 ; 91 ; 41-6$.

http://dx.doi.org/10.1016/0304-3835(94)03716-V 
[45] May W Jr, Cuatrecasas P. Transferrin receptor: its biological significance. J Membr Biol 1985; 88: 205-15.

[46] Singh N, Lai H. Selective toxicity of dihydroartemisinin and holotransferrin toward human breast cancer cells. Life Sci 2001; 70: 49-56.

[47] Bulter AR, Gilbert BC, Hulme P, Irvine LR, Renton L, et al. EPR evidence for the involvement of free radicals in the ironcatalysed decomposition of Qinghaosu (Artemisinin) and some derivatives; antimalarial action of some polycyclic endoperoxides. Free Radic Res 1998; 28: 471-6. http://dx.doi.org/10.3109/10715769809066884

[48] Moore JC, Lai H, Li JR, Ren RL, McDougall JA, et al. Oral administration of dihydro-artemisinin and ferrous sulfate retarded implanted fibrosarcoma growth in rat. Cancer Lett 1995; 98: 83-7. http://dx.doi.org/10.1016/S0304-3835(06)80014-5

[49] Anfosso L, Efferth T, Albini A, Pfeffer U. Microarray expression profiles of angiogenesis-related gene predict tumor cell response to artemisinins. J Pharmacogenomics 2006; 6: 269-78. http://dx.doi.org/10.1038/sj.tpj.6500371

[50] Vanamala J, Reddivari L, Radhakrishnan S, Tarver C. Resveratrol suppresses IGF-1 induced human colon cancer cell proliferation and elevates apoptosis via suppression of IGF-1R/Wnt and activation of p53 signaling pathways. BMC Cancer 2010; 10: 238.

http://dx.doi.org/10.1186/1471-2407-10-238

[51] Majumdar AP, Banerjee S, Nautiyal J, Patel BB, Du J, et al. Curcumin synergizes with resveratrol to inhibit colon cancer. Nutr Cancer 2009; 61(4): 544-53. http://dx.doi.org/10.1080/01635580902752262

[52] Leonard SS, Xia C, Jiang BH, Stinefelt B, Klandorf $\mathrm{H}$, et al. Resveratrol scavenges reactive oxygen species and effects radical-induced cellular responses. Biochem Biophys Res Commun 2003; 309(4): 1017-26.

http://dx.doi.org/10.1016/j.bbrc.2003.08.105

[53] Clark LC, Combs GR Jr, Turnbull BW, Slate EH, Chalker DK, et al. Effects of selenium supplementation for cancer prevention in patients with carcinoma of the skin: a randomized controlled trial. Nutritional Prevention of Cancer Study Group. JAMA 1996; 276: 1957-63. http://dx.doi.org/10.1001/jama.1996.03540240035027

[54] National Research Council Staff. Diet and Health: Implications for Reducing Chronic Disease Risk. Washington, DC: National Academy of Education 1989; pp. 376-9.

[55] Schrauzer G. The nutritional significance, metabolism and toxicology of selenomethionine. Adv Food Nutr Res 2003; 47: 73-112.

[56] Tisdale M. Cancer cachexia. Anticancer Drugs 1993; 4(2): 115-25.

[57] Mason J, Lavesque T. Folate: effects on carcinogenesis and the potential for cancer chemopreventon. Oncology 1996; 10: 1727-43.

[58] Kim Y, Mason J. Folate, epithelial dysplasia, and colon cancer. Proc Assoc Am Physicians 1995; 107: 218-27.

[59] Tseng M, Murray SC, Kupper LL, Sandler RS. Micronutrients and the risk of colorectal adenomas. Am J Epidemiol 1996; 144: 1005-14.

[60] Jaszewski R, Misra S, Tobi M, Ullah N, Naumoff JA, et al. Folic acid supplementation inhibits recurrence of colorectal adenomas: A randomized chemoprevention trial. World $\mathrm{J}$ Gastroenterol 2008; 14: 4492-8. http://dx.doi.org/10.3748/wjg.14.4492

[61] Pence B. Role of calcium in colon cancer prevention: experimental and clinical studies. Mutat Res 1993; 290: 8795.

http://dx.doi.org/10.1016/0027-5107(93)90036-F
[62] Bostick RM, Fosdick L, Wood JR, Grambsch P, Grandits GA, et al. Calcium and colorectal epithelial cell proliferation in sporadic adenoma patients: a randomized, double-blinded, placebo-controlled clinical trial. J Natl Cancer Inst 1995; 87: 1307-15. http://dx.doi.org/10.1093/jnci/87.17.1307

[63] Holt PR, Atillasoy EO, Gilman J, Guss J, Moss SF, et al. Modulation of abnormal colonic epithelial cell proliferation and differentiation by low-fat dairy foods: a randomized controlled trial. JAMA 1998; 280: 1074-9. http://dx.doi.org/10.1001/jama.280.12.1074

[64] Baron JA, Beach M, Mandel JS, van Stolk RU, Haile RW, et al. Calcium supplements for the prevention of colorectal adenomas. N Engl J Med 1999; 340: 101-7. http://dx.doi.org/10.1056/NEJM199901143400204

[65] Weingarten MA, Zalmanovici A, Yaphe J. Dietary calcium supplementation for preventing colorectal cancer and adenomatous polyps. Cochrane Database Syst Rev 2008; CD003548. http://dx.doi.org/10.1002/14651858.CD003548.pub4

[66] Grau MV, Baron JA, Sandler RS, Wallace K, Haile RW, et al. Prolonged effect of calcium supplementation on risk of colorectal adenomas in a randomized trial. J Natl Cancer Inst 2007; 99: 129-36.

[67] Larsson SC, Orsini N, Wolk A. Diabetes Mellitus and risk of colorectal cancer: A Meta-Analysis. J Natl Cancer Inst 2005; 97(2): 1679-87.

http://dx.doi.org/10.1093/jnci/dji375

[68] Greenberg ER, Baron JA, Tosteson TD, Freeman DH, Beck GJ, et al. A clinical trial of antioxidant vitamins to prevent colorectal adenoma. N Engl J Med 1994; 331: 141-7. http://dx.doi.org/10.1056/NEJM199407213310301

[69] Macready N. Vitamins associated with lower colon-cancer risk. Lancet 1997; 350: 1452. http://dx.doi.org/10.1016/S0140-6736(05)64218-3

[70] White E, Shannon JS, Patterson RE. Relationship between vitamin and calcium supplement use and colon cancer. Cancer Epidemiol Biomarkers Prev 1997; 6: 769-74.

[71] Bostick RM, Potter JD, McKenzie DR, Sellers TA, Kushi LH, et al. Reduced risk of colon cancer with high intake of vitamin E: the lowa Women's Health Study. Cancer Res 1993; 53: 4230-7.

[72] Martinez ME, Giovannucci EL, Colditz GA, Stampfer MJ, Hunter DJ, et al. Calcium, vitamin D, and the occurrence of colorectal cancer among women. J Natl Cancer Inst 1996; 88(19): 1375-82. http://dx.doi.org/10.1093/jnci/88.19.1375

[73] Kearney J, Giovannucci E, Rimm EB, Ascherio A, Stampfer $\mathrm{MJ}$, et al. Calcium, vitamin $\mathrm{D}$, and dairy foods and the occurrence of colon cancer in men. Am J Epidemiol 1996; 143(9): 907-17.

[74] McCullough ML, Robertson AS, Rodriquez C, Jacobs EJ, Chao $A$, et al. Calcium, vitamin D, dairy products, and risk of colorectal cancer in the Cancer Prevention Study II Nutrition Cohort (United States). Cancer Causes Control 2003; 14(1): $1-12$.

[75] Lieberman DA, Prindiville S, Weiss DG, Willet W, VA Cooperative Study Group 380. Risk factors for advanced colonic neoplasia and hyperplastic polyps in asymptomatic individuals. JAMA 2003; 290(22): 2959-67. http://dx.doi.org/10.1001/jama.290.22.2959

[76] Benito E, Obrador A, Stiggelbout A, Bosch FX, Mulet M, et al. A population-based case-control study of colorectal cancer in Majorca, I: dietary factors. Int J Cancer 1990; 45(1): 69-76.

[77] Baron JA, Cole BF, Sandler RS, Haile RW, Ahnen D, et al. A randomized trial of aspirin to prevent colorectal adenomas. $\mathrm{N}$ Engl J Med 2003; 238(10): 891-9. http://dx.doi.org/10.1056/NEJMoa021735 
[78] Thun MJ, Namboodiri MM, Heath CW Jr. Aspirin use and reduced risk of fatal colon cancer. N Engl J Med 1991; 325(23): 1593-6. http://dx.doi.org/10.1056/NEJM199112053252301

[79] Dube C, Rostom A, Lewin G, Tsertsvadze A, Barrowman N, et al. The use of aspirin for primary prevention of colorectal cancer: a systematic review prepared for the U.S. Preventive Services Task Force. Ann Intern Med 2007; 46(5): 365-75. http://dx.doi.org/10.7326/0003-4819-146-5-200703060$\underline{00009}$

[80] He J, Whelton PK, Vu B, Klaq MJ. Aspirin and risk of hemorrhagic stroke: a meta-analysis of randomized controlled trials. JAMA 1998; 280(22): 1930-5.

http://dx.doi.org/10.1001/jama.280.22.1930

[81] Markowitz SD, Bertagnolli MM. Molecular basis of colorectal cancer. N Engl J Med 2009; 361(25): 2449-60. http://dx.doi.org/10.1056/NEJM ra0804588

[82] National Cancer Registry Report 2007. Malaysian Cancer Statistics: Data and Facts. Non-Communicable Disease Section. Malaysia: Ministry of Health 2011; p. 36.

[83] Cunningham D, Atkin W, Lenz HJ, Lynch HT, Minsky B, et al. Colorectal cancer. Lancet 2010; 375 (9719): 1030-47. http://dx.doi.org/10.1016/S0140-6736(10)60353-4

[84] Bassaganya-Riera J, Reynolds K, Martino-Catt S, Cui Y, Hennighausen L, et al. Activation of PPAR gamma and delta by conjugated linoleic acid mediates protection from experimental inflammatory bowel disease. Gastroenterology 2004; 127(3): 777-91.

http://dx.doi.org/10.1053/j.gastro.2004.06.049

[85] Bian $\mathrm{Y}$, Caldes $\mathrm{T}$, Winnen J, Franken $\mathrm{P}$, Vasen $\mathrm{H}$, et al. TGFBR1/6A may contribute to hereditary colorectal cancer. J Clin Oncol 2005; 23(13): 3074-8. http://dx.doi.org/10.1200/JCO.2005.00.281

[86] Astin M, Griffin T, Neal RD, Rose P, Hamilton WI. The diagnostic value of symptoms for colorectal cancer in primary care: a systematic review. Br J Gen Pract 2011; 61(586): 231-43.

http://dx.doi.org/10.3399/bjgp11X572427

[87] Grant J. Proper use and recognized role of TPN in the cancer patient. Nutrition 1990; 6(4): 6s-7s.

[88] National Cancer Institute. http://www.uicc.org/membership/ national-cancer-institute-usa. Accessed: July 20, 2013.

[89] Jawad N, Direkze N, Leedham SJ. Inflammatory bowel disease and colon cancer. Recent results in cancer research. Fortschritte der Krebsforschung 2011; 185: 99-115. http://dx.doi.org/10.1007/978-3-642-03503-6 6

[90] Larsson SC, Giovannucci E, Bergkvist L, Wolk A. Whole grain consumption and risk of colorectal cancer: a population-based cohort of 60,000 women. $\mathrm{Br} \mathrm{J}$ Cancer 2005; 92(9): 1803-7.

[91] Allen TD, Moore DR, Wang X, Casu V, May R, et al. Dichotomous metabolism of Enterococcus faecalis induced by haematin starvation modulates colonic gene expression. $\mathrm{J}$ Med Microbiol 2008; 57: 1193-204.

http://dx.doi.org/10.1099/jmm.0.47798-0

[92] Garland C, Shekelle RB, Barrett-Connor E, Crique MH, Rossoff $\mathrm{AH}$, et al. Dietary vitamin $\mathrm{D}$ and calcium and risk of colorectal cancer: a 19-year prospective study in men. Lancet 1985; 1(8424): 307-9.

http://dx.doi.org/10.1016/S0140-6736(85)91082-7

[93] Garland CF, Comstock GW, Garland FC, Helsing KJ, Shaw $\mathrm{EK}$, et al. Serum 25-hydroxyvitamin $\mathrm{D}$ and colon cancer: eight-year prospective study. Lancet 1989; 2: 1176-8. http://dx.doi.org/10.1016/S0140-6736(89)91789-3

[94] Garland C and Garland F. Do sunlight and vitamin D reduce the likelihood of colon cancer? Int J Epidemiol 1980; 9(3): 227-31.

\section{http://dx.doi.org/10.1093/ije/dyi229}

[95] Peters U, McGlynn KA, Chatterjee N, Gunter E, GarciaClosas $\mathrm{M}$, et al. Vitamin $\mathrm{D}$, calcium, and vitamin $\mathrm{D}$ receptor polymorphism in colorectal adenomas.Cancer Epidemiol Biomarkers Prev 2001; 10(12): 1267-74.

[96] Grau MV, Baron JA, Sandler RS, Haile RW, Beach ML, et al. Vitamin D, calcium supplementation, and colorectal adenomas: results of a randomized trial. J Natl Cancer Inst 2003; 95(23): 1765-71.

http://dx.doi.org/10.1093/jnci/djg110

[97] Feskanich D, MaJ, Fuchs CS, Kirkner GJ, Hankinson SE, et al. Plasma vitamin $D$ metabolites and risk of colorectal cancer in women. Cancer Epidemiol Biomarkers Prev 2004; 13(9): 1502-8.

[98] Tangrea J, Helzlsouer K, Pietinen P, Taylor P, Hollis B, et al. Serum levels of vitamin $D$ metabolites and the subsequent risk of colon and rectal cancer in Finnish men. Cancer Causes Control 1997; 8(4): 615-25. http://dx.doi.org/10.1023/A:1018450531136

[99] Braun MM, Helzlsouer KJ, Hollis BW, Comstock GW. Colon cancer and serum vitamin D metabolite levels 10-17 years prior to diagnosis. Am J Epidemiol 1995; 142(6): 608-11.

[100] Lipkin $M$ and Newmark $\mathrm{H}$. Effect of added dietary calcium on colonic epithelial cell proliferation in subjects at high risk for familial colon cancer. N Engl J Med 1985; 313: 1381-4. http://dx.doi.org/10.1056/NEJM198511283132203

[101] Lamprecht S, Lipkin M. Migrating colonic crypt epithelial cells: primary targets for transformation. Carcinogenesis 2002; 23(11): 1777-80.

http://dx.doi.org/10.1093/carcin/23.11.1777

[102] Ravasco P, Monteiro-Grillo I, Vidal PM, Camilo ME. Cancer: disease and nutrition are key determinants of patients' quality of life. Support Care Cancer 2004; 12(4): 246-52. http://dx.doi.org/10.1007/s00520-003-0568-z

[103] Morgan G, Ward R, Barton M. The Contribution of Cytotoxic Chemotherapy to 5-year Survival in Adult Malignancies. Clin Oncol 2004; 16: 549-60. http://dx.doi.org/10.1016/i.clon.2004.06.007

[104] Fisher D, Malpas P, Dominitz J, Cash B, Evas J, et al. Complications of colonoscopy. Gastrointestional Endoscopy 2011; 74(4): 745-52.

http://dx.doi.org/10.1016/..gie.2011.07.025

[105] Winawer SJ, Zauber AG, Ho MN, O'Brian MJ, Gottlieb LS, et al. Prevention of colorectal cancer by colonoscopic polypectomy. The National Polyp Study Workgroup. N Engl J Med 1993; 329(27): 1977-81.

http://dx.doi.org/10.1056/NEJM199312303292701

\section{DOI: http://dx.doi.org/10.6000/1927-3037.2013.02.03.4}

\section{(c) 2013 Steve Yap; Licensee Lifescience Global.}

This is an open access article licensed under the terms of the Creative Commons Attribution Non-Commercial License (http://creativecommons.org/licenses/by-nc/3.0/) which permits unrestricted, non-commercial use, distribution and reproduction in any medium, provided the work is properly cited. 